Çukurova Üniversitesi Mühendislik Mimarlık Fakültesi Dergisi, 30(1), 87-94 ss., Haziran 2015

Çukurova University Journal of the Faculty of Engineering and Architecture, 30(1), pp. 87-94, June 2015

\title{
Design and Analysis of Electrically Operated Golf Cart Chassis Using FEA
}

\author{
Durmuş Ali BİRCAN ${ }^{* 1}$, Kerem SELVİ ${ }^{2}$ Ayhan ERTAŞ ${ }^{2}$, Ali YALTIRIK ${ }^{2}$ \\ ${ }^{l}$ C.Ü., Mühendislik-Mimarlık Fakültesi, Makine Mühendisliği Bölümü, Adana \\ ${ }^{2}$ Makine Mühendisi
}

\begin{abstract}
Geliş tarihi: 26.02 .2015

Kabul tarihi: 24.06 .2015

The significant challenge in today's automotive industry is to defeat the increasing demands for higher performance, longer life, and lower weight of components in order to satisfy fuel economy requirements at a realistic cost using safety requirements. The aim of this study is to design and analyze the chassis of an electrically operated golf cart for use in Çukurova University campus. Chassis is a frame just like skeleton on which various machine parts like engine, tires, axle assemblies, brakes, steering etc. are joined. It gives strength and stability to the vehicle under different conditions. The main function of the chassis is not only to support the components and payload mounted upon it including engine, body, passengers and luggage, but also to maintain the desired relationship between the suspension and steering mechanism mounting points. In this study; 3D models of chassis were designed using SolidWorks by considering different types of profiles. Structural analyses were conducted on the golf cart chassis with various materials and profiles via ANSYS software using Finite Elements Analysis (FEA) method. The aim of the design was to achieve sufficient strength and minimum deflection values with optimum weight, cost and ease of manufacturing.
\end{abstract}

Keywords: Electric golf cart chassis, Computer aided design (CAD), Finite element analysis (FEA), ANSYS

\section{Sonlu Eleman Analizi Kullanarak Elektrikli Golf Aracı Şasesi Tasarım ve Analizi}

\section{Özet}

Günümüz otomotiv endüstrisinde yüksek performans, uzun ömür ve minimum yakıt tüketim şartlarını sağlayacak düşük ağırlıklı parçalara yönelik artan bir talep bulunmaktadır. Bu talebi gerçekçi maliyetle ve güncel güvenlik gereksinimlerine uyarak karşılamak önemli bir sorun teşkil etmektedir. Bu çalışmanın amacı; Çukurova Üniversitesi kampusu içerisinde kullanılacak elektrikli golf aracı şasesinin tasarımını ve analizlerini yapmaktır. Şasi, tıpkı bir iskelet gibi üzerine motor, tekerlek, fren, direksiyon, aks gibi çeşitli parçaların monte edildiği bir yapıdır. Araca çeşitli şartlar altında mukavemet ve denge sağlar. Şasinin ana işlevi sadece üzerindeki parçaları ve motor, karoser, yolcular, bagaj gibi yükleri taşımak değil, ayrıca süspansiyon ve direksiyon mekanizmalarının bağlantı noktaları arasındaki istenen etkileşimi

\footnotetext{
*Yazışmaların yapılacă̆ı yazar: Durmuş Ali BİRCAN, Ç.Ü., Mühendislik-Mimarlık Fakültesi, Makine Mühendisliği Bölümü, Adana, abircan@cu.edu.tr
} 
sağlamaktır. Bu çalışmada, SolidWorks programı yardımıyla, farklı profil tipleri göz önünde bulundurularak üç boyutlu bir şasi tasarlanmıştır. Yapı analizleri ANSYS yazılımı kullanılarak Sonlu Eleman Analizi metoduyla gerçekleştirilmiştir. Tasarımın hedefi gerekli mukavemet ve minimum çökme değerlerini optimum ağırlık ve maliyetle sağlamaktır.

Anahtar Kelimeler: Elektrikli golf aracı şasesi, Bilgisayar destekli tasarım, Sonlu eleman analizi, ANSYS

\section{INTRODUCTION}

Over the last three decades, there has been an increasing requirement to lower vehicle mass. This has been driven by two factors; increasing petrol prices due to shortages in supply of crude oil and an increasing awareness of the environment and the need to reduce exhaust emissions. Lowering the mass leads to less energy being required from the motor to accelerate and drive an automobile. These lower energy requirements mean emissions and petrol usage from a lighter vehicle will be less than for a heavier comparable car. The automobile industry's drive for lower vehicle emissions and energy consumption has led to the development of alternative means of propulsion, in particular Battery Electric Vehicles (BEV). The improvements have increased battery energy density which allows substantial improvements to driving range. Increasing range allows electric vehicles to be driven like conventional internal combustion engine vehicles.

There are a lot of advantages of driving an electric car. The first thing that considered is that electric vehicles don't pollute the atmosphere although the power plant producing the necessary electricity is likely to somewhat polluting. More and more power plants are looking for more efficient ways of using solar panels, though. Bottom line is that electric cars are environmentally friendly: no exhaust fumes come out of them. They are also quite energy efficient: electric motors manage to convert around $75 \%$ of the chemical energy from their batteries to power the wheels of the car, while internal combustion engines only converted about $20 \%$ of the energy that could be provided by the gas. Electric motors are also quiet and they don't require a lot of maintenance.
This study was undertaken as a project to design and construct a lightweight chassis for an electric car with a capacity of 6 passengers for use in Çukurova University campus. To design an electric vehicle, the chassis must be designed based on the requirements and the ability of the electric energy. The components involved in building the electric vehicle must be considered. The main components that will give an effect to the design of the chassis are the electric motor and the battery. The size, weight and the position of these components must be considered before designing the chassis.

\subsection{Chassis in Vehicles}

The chassis is the main structural frame of an automobile. It connects all key components including suspension and drive train. There are five main functions of chassis; to provide an area for occupants and luggage, offer safety to the occupants and outside parties, provide points for mounting of suspension and drive train, and provide a stiff framework linking all mounting points. The mounting of components must be rigid as large movements may cause components to interfere and thus not function intended. This section covers the function of a chassis, the different types of chassis. From the review, a suitable chassis for the electric car will be designed.

Ladder Frame Chassis: The ladder frame consists of two longitudinal beams with multiple cross members joining the beams. It is versatile as allows virtually anybody shape to be placed a top the chassis. The ladder frame chassis, as shown in Figure 1, is very durable due to its simplicity. If damage was occurred, it is much easier to repair 
than other types of chassis. The longitudinal beams are very stiff under bending through the use of closed section beams with a high second moment of area. The high bending stiffness makes the ladder frame chassis well suited for carrying large weights.

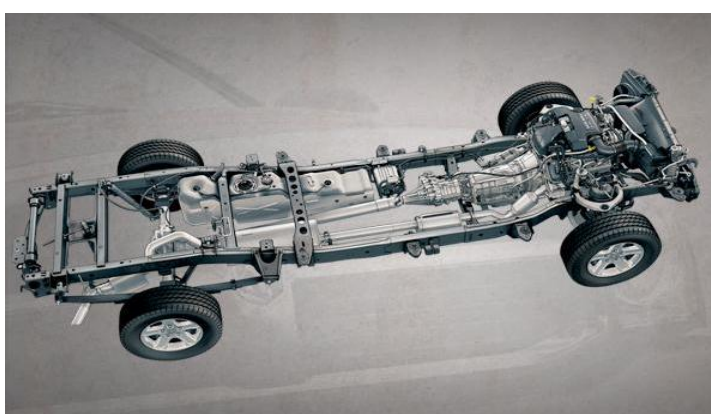

Figure 1. A Dodge Ram 2500 ladder frame chassis [1]

Backbone (Torque Tube) Chassis: It is the main alternative solution to the ladder frame chassis. The backbone chassis design consists of a single, large, longitudinal structural beam running down the center of the vehicle with lateral beams connecting the suspension. The suspension and motor lateral beams are mounted off the backbone.

Space Frame Chassis: It is light due to the minimal amount of structural material that is necessary. The required amount of material is minimal because of the triangulated design which keeps all beams under tension or compression but, not torsion. With the beams not under torsion, the cross sectional area of the beams can be reduced. An increase in stiffness compared to the ladder frame and backbone chassis originates from the three dimensional shape adding height to the design (Figure 2.).

Monocoque Chassis: A monocoque or uni-body chassis, as presented in Figure 3, is a chassis that is integral with the body. It is the chassis of choice for most major car manufacturers, equating to $99 \%$ of modern vehicles [3]. The monocoque chassis is very complex yet cheap to produce, has large spaces and is very safe but has rigidity to weight ratio similar to a ladder frame chassis. The complexity of the chassis is due to the integration with the body shell. The integration makes set up costs large as the development of the chassis requires considerable time and money.

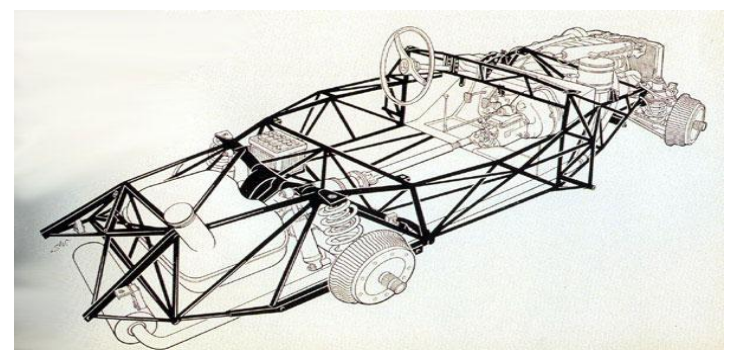

Figure 2. Mercedes Benz 300SL space frame chassis [2]

Tub Chassis: The Lotus Tub is a development which progressed from the backbone chassis. It takes many small cross sectional extrusions and glues them together to create large beams that run the length of the vehicle. Unlike ladder frame design the passenger actually sits between these large beam members providing a strong passenger compartment protecting against impact. The weaker passenger compartment is stabilized by the front and rear area which heavily connects the sides.

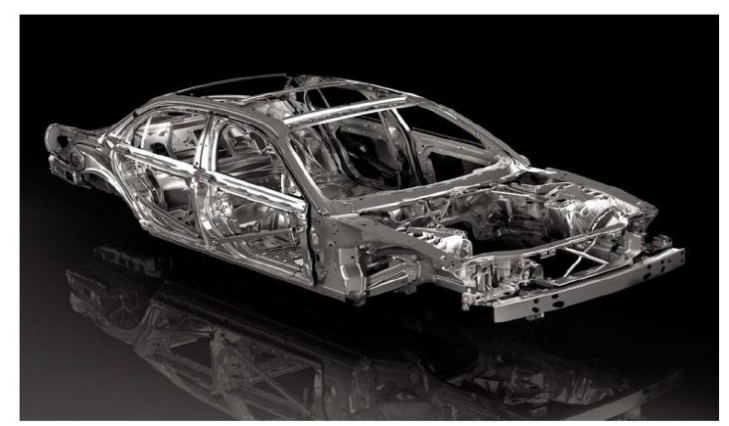

Figure 3. The Aluminum Jaguar XJ monocoque chassis [4]

\subsection{Finite Element Analysis}

The Finite Element Method (FEM) is a powerful tool for the numerical procedure to obtain solutions to many problems encountered in 
engineering analysis. Structural, thermal and heat transfer, fluid dynamics, fatigue related problems, electric and magnetic fields, the concepts of FE methods can be utilized to solve these engineering problems. In this method of analysis, a complex region is discretized into simple geometric shapes called finite elements the domain over which the analysis is studied is divided into a number of finite elements. The software implements equations that govern the behavior of these elements and solves them all; creating a comprehensive explanation of how the system acts as a whole. These results then can be presented in tabulated or graphical forms. This type of analysis is typically used for the design and optimization of a system far too complex to analyze by hand. Created geometric models are transferred to the ANSYS program to be done FEA. Selection of element type on the mathematical model, creating the mesh form, determining the contact areas, boundary conditions, environment and material properties and the type of analysis have been made in the program interface.

\section{LITERATURE REVIEW}

FE methods that currently are used extensively in academia and industry. The method described in general terms, the basic formulation is presented, and some issues regarding effective FE procedures are summarized.

Demeng [5] was performed research on lightweight design of automobile structure based on ANSYS by using FEM. The kind of FE model of the frame of a semi-trailer was established based on ANSYS and stress calculation and experiment validation simulating the actual working conditions were performed. Then, the math model of optimal design was formed from the analysis result of FEM.

Bircan, et al. [6] were stated that two types of space and ladder frames were considered with three types of materials as steel, aluminum and titanium. Displacement values were generated for two frames with three materials and torsional stiffness values obtained using FEA software
ANSYS. It was concluded that maximum torsional stiffness value $307,692 \mathrm{Nm} / \mathrm{deg}$ was obtained from space frame with material of steel while the minimum value $30,769 \mathrm{Nm} / \mathrm{deg}$ obtained from ladder frame with material of aluminum.

Agrawal and Razik [7] were performed the optimization of the automotive chassis with constraints of maximum shear stress, equivalent stress and deflections under maximum load. A sensitivity analysis was carried out for weight reduction. It was shown that proper FE model of the TATA 1612 chassis has to be developed by using actual parameter which was modeled in CATIA v5. Sitaramanjaneyulu and Raju [8] were studied the maximum equivalent stress and total deformation formed on the heavy truck when different loads were applied. Two types of analysis were done to study the behavior of the geometry using advanced modeling software CATIA. Lovatt [3] was performed the development of a lightweight electric vehicle chassis and investigation into the suitability of TiAl for automotive applications. A lightweight chassis for a battery electric vehicle being developed at the University of Waikato was required. The chassis was designed around a predetermined body shape and suspension setup. A chassis, built from $20 \mathrm{~mm}$ thick aluminum honeycomb sandwich panel, was designed and built to LVVTA standards allowing the car to be driven on public roads. The chassis weighs a little over a third the mass of a mass production car chassis.

Hirsch [9] was designed innovative light-weight car design using aluminum. Weight saving in the chassis can also achieve $40 \%$ in comparison to conventional steel chassis. It has the additional benefit of improving the driving dynamics, ride comfort, and safety due to the reduction of the unsprung mass. Teh and Tong [10] was performed a structural investigation of an electric car chassis. Their analysis was focused primarily on the main frame and suspension arm. There were two concepts each for both the chassis and the suspension arm. These concepts were simulated to determine the optimum balance between weight and rigidity. Torsional rigidity was analyzed for 
the chassis while static force, braking torque test and cornering test were performed for the suspension arm. The results showed that the stressed skin chassis concept and three tube suspension arms had higher rigidity. Riley and George [10] were studied design, analysis and testing of a formula SAE car chassis. The different loading conditions and requirements of the vehicle frame are first discussed focusing on road input and load paths within the structure. Next, simple spring model was developed to determine targets for frame and overall chassis stiffness. This model examines the frame and overall chassis torsional stiffness relative to the suspension spring and antiroll bar rates. A finite element model was next developed to enable the analysis of different frame concepts.

\section{MATERIAL AND METHODS 3.1. Design Process}

The design process is a series of steps that is followed to come up with a solution to a problem. Steps of the design process involved in this study are shown in the Figure 4. At the beginning of the design process, design geometry has been defined according to design specifications as shown in Table 1. Five selected profiles for each of the three materials are applied to designed geometry and imported to ANSYS for analysis. To determine actual loading conditions for the analysis, passenger capacity (6 passengers), weight of the vehicle components (electric motor, suspension, steering mechanism etc.) and batteries $(6 \times 31 \mathrm{~kg})$ have been considered and a total load of $9 \mathrm{kN}$ (approximately $920 \mathrm{~kg}$ ) has been applied to the chassis. After applying the boundary conditions, structural analyses were conducted and updated until satisfactory design solutions were obtained.

\subsection{Design Considerations for Electric Car Chassis}

The analytical calculations for the considered chassis were done using basic design calculations. The pre-required data considered are as follows: Materials: Chassis must be rigid and strong enough to carry the designated load and achieve minimum deflection with minimum weight and cost. In this study, three different materials were used. These are AISI 1020 Structural Steel, 6061-

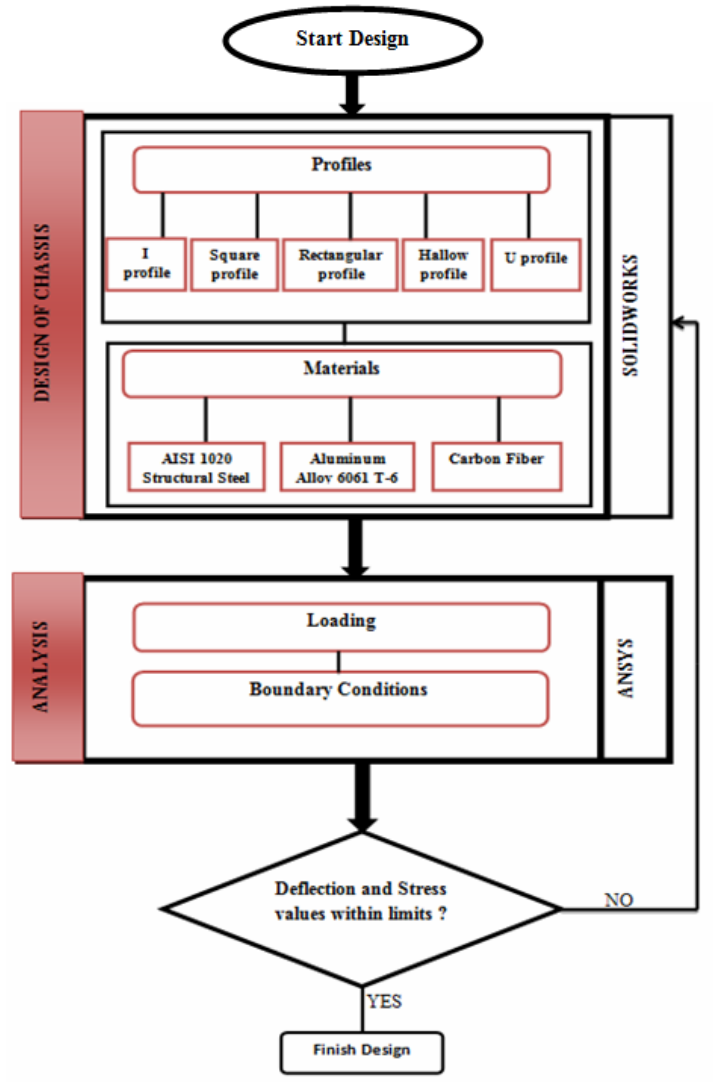

Figure 4. Proposed design and analysis steps

Table 1. The specifications of the designed chassis

\begin{tabular}{|l|l|}
\hline Criteria & Specifications \\
\hline Chassis & $\begin{array}{l}\text { Lightweight, High } \\
\text { dimensional stability, } \\
\text { Excellent } \\
\text { impact/stiffness balance, } \\
\text { have aesthetic value and } \\
\text { suitable for use in } \\
\text { campus conditions. }\end{array}$ \\
\hline Ground clearance & $220 \mathrm{~mm}$ \\
\hline Wheelbase & $2500 \mathrm{~mm}$ \\
\hline Seating capacity & 6 person \\
\hline Dimensions (LxW) & $3200 \times 1305 \mathrm{~mm}$ \\
\hline
\end{tabular}


T6 Aluminum Alloy and Carbon Fiber. Material properties can be seen in Table 2. Profile: At the design of chassis, five different profile types and dimensions, as shown in Figure 8, were considered. These are; I profile, U Profile, Hollow Square Profile, Circular Tube Profile, and Hollow Rectangular Profile (Figure 5).

Table 2. Material properties of AISI 1020 steel, aluminum alloy 6061 T-6 and carbon fiber.

\begin{tabular}{|l|c|c|c|}
\hline \multicolumn{1}{|c|}{ Properties } & $\mathbf{1 0 2 0}$ & $\mathbf{6 0 6 1 T - 6}$ & $\begin{array}{c}\text { Carbon } \\
\text { Fiber }\end{array}$ \\
\hline Density $\left(\mathrm{kg} / \mathrm{m}^{3}\right)$ & 7900 & 2700 & 1570 \\
\hline Elastic Modulus(GPa) & 200 & 69 & 190 \\
\hline Yield Strength $(\mathrm{MPa})$ & 352 & 275 & 200 \\
\hline Tensile Strength $(\mathrm{MPa})$ & 420 & 310 & 480 \\
\hline Poisson's Ratio & 0,29 & 0,33 & 0,25 \\
\hline
\end{tabular}

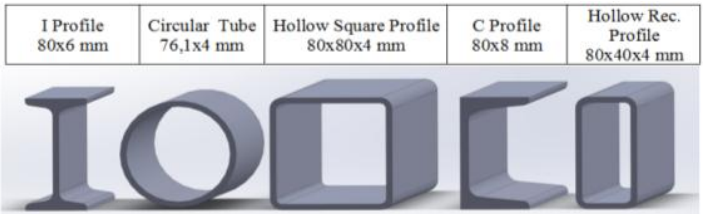

Figure 5. Profile types

The electric car chassis was designed in SolidWorks Computer Aided Design (CAD), software which is feature based, parametric solid modeling program (Figure 6). Created geometric models are transferred to the ANSYS program to be done for FEA.

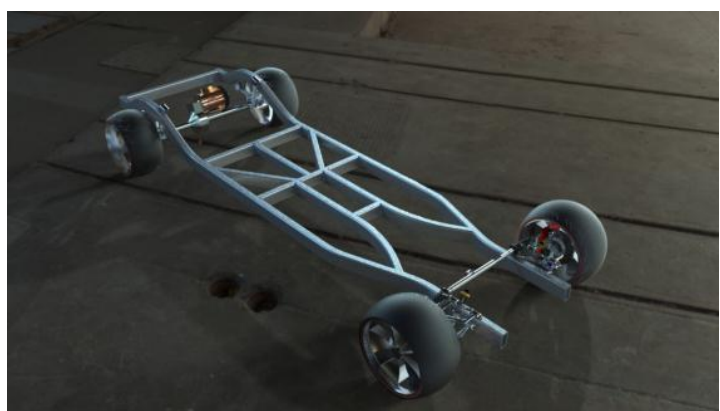

Figure 6. Final presentation of the designed chassis

\section{RESULTS and DISCUSSION}

For FEA, CAD model of electric vehicle chassis is created and imported to ANSYS. For the analysis, a distributed load of $9 \mathrm{kN}$ applied on the chassis, as shown in Figure 7, by considering passenger capacity, the weight of the vehicle components, and batteries.

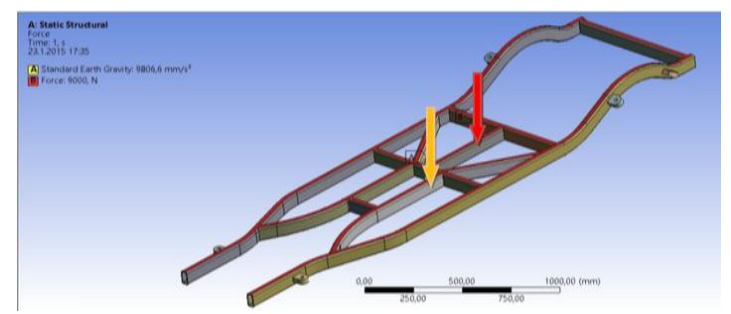

Figure 7. Distribution of loads on chassis

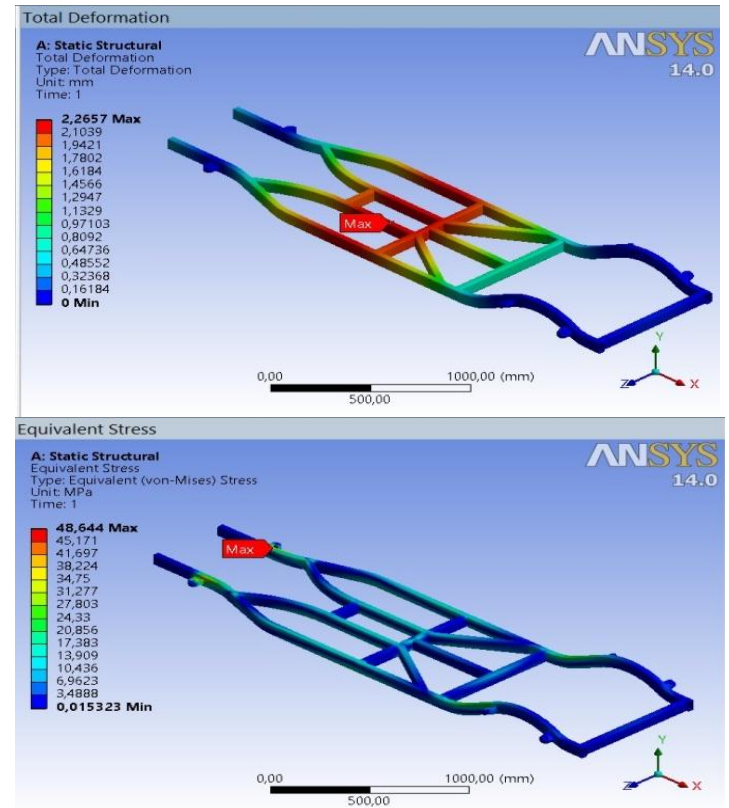

Figure 8. Total deformation and von-misses stresses of aluminum alloy 6061 t-6 chassis

The analyses have been conducted with three different materials. The aim of the design was to obtain a minimum deflection value. Using these boundary conditions, total deformation and von- 
Misses stress in electric vehicle chassis have been obtained as illustrated in Figure 8 to Figure 10.
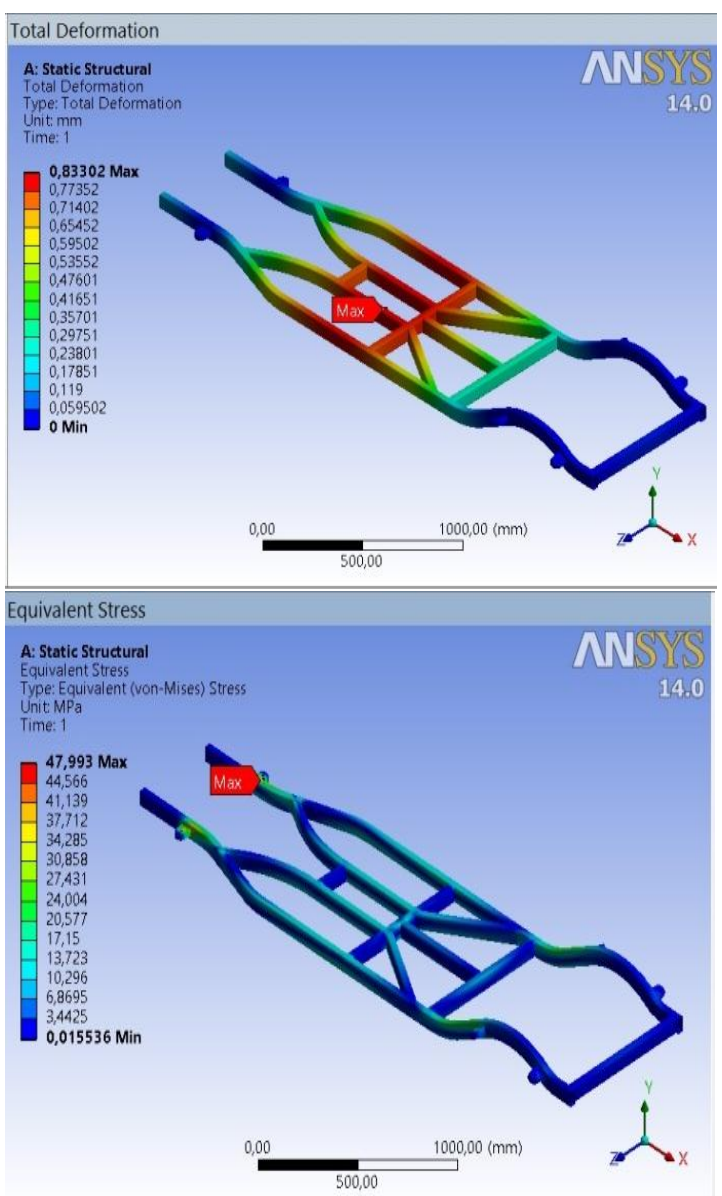

Figure 9. Total deformation and von-misses stresses of carbon fiber chassis.

Total deflection values obtained from the analyses for all material and profile combinations are represented in Figure 11 for ease of comparison. Total weight values obtained from the analyses for all three materials and five profiles are represented in Figure 12.

Consequently, hollow rectangular profile with $80 \times 40 \mathrm{~mm}$ dimensions and $4 \mathrm{~mm}$ thickness has been selected as the final selection of profile. Considering material selection, 6061 T-6 aluminum alloy have failed to give a resultant deflection below $1 \mathrm{~mm}$, therefore it's not preferred.
As can be seen in Figures 10 to 13, optimum results were obtained using carbon fiber with hollow rectangular profile, but high cost of this material makes it unfeasible to use for small scale productions. Since, the stresses are relatively lower, yielding is not a practical problem in the design. This makes the modulus of elasticity is the distinctive property for material choice. AISI 1020 structural steel is chosen due its low cost, because even the strongest and most expensive steels have the same modulus of elasticity and would give the same results in terms of deflection.
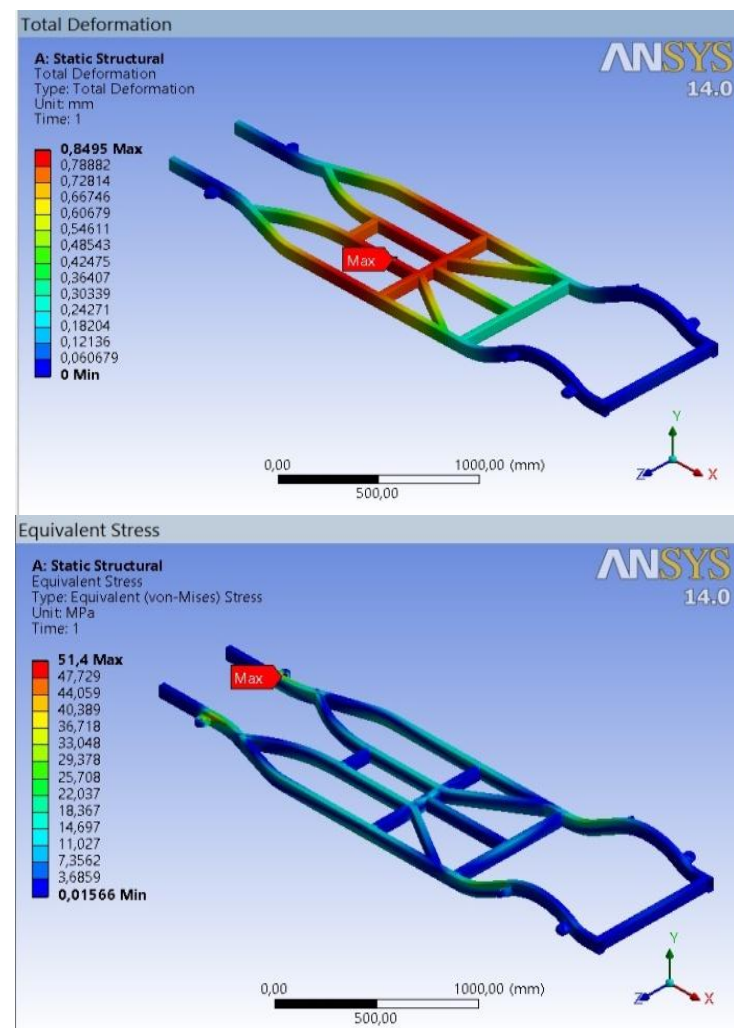

Figure 10. Total deformation and von-misses stresses of aisi 1020 structural steel chassis

\section{CONCLUSION}

In this study, design and analysis of the electric vehicle chassis which will be used in Çukurova University campus have been carried out in order 
to determine optimal design parameters. The chassis was designed using 3D parametric software SolidWorks and the analyses were conducted using ANSYS via FEA method. The development and application of the FEA considerably reduce the time and effort required for the chassis design process. The chassis was designed so as the vehicle can withstand the loads with a specific strength and stiffness while considering weight, cost and ease of manufacturing. Following conclusions may be drawn:

Analyses have been performed by varying the material and profile types for the chassis. AISI 1020 Structural Steel, Aluminum Alloy 6061 T- 6 and Carbon Fiber materials have been used in combination with five different profile types. Namely; I, U, Hollow Square, Circular Tube, and Hollow Rectangular.

$>$ Results show that for all material-profile combinations, maximum stresses were below the yield stress indicating the design was safe in terms of static strength.

$>$ Optimum results in terms of total deformation and weight have been obtained using Carbon Fiber with $80 \times 40 \times 4 \mathrm{~mm}$ hollow rectangular profile. When cost is taken into consideration for small scale production, AISI 1020 Structural Steel with the same profile appears to be the optimum

\section{Acknowledgements}

Authors would like to thank to the Scientific and Technological Research Council of Turkey (TÜBİTAK) for funding to support this study under 2241-A Industry Oriented Undergraduate Project Support Program.

\section{REFERENCES}

1. Chrysler, L., 2007. RAM 2500 Hydro-formed ladder ww.dodge.com/en/2007/ram_2500/ 13.01.2015.

2. Rastkar, A. R., Bell, T., 2002. Tribological Performance of Plasma Nitride Gamma Based
Titanium Aluminates; Wear, 253, p: 1121-1131.

3. Lovatt, C.R., 2008. The Development of a Lightweight Electric Vehicle Chassis and Investigation into the Suitability of TiAl for Automotive Applications'; Ms. Degree, Mechanical Engineering; The University of Waikato at Hamilton, New Zealand.

4. Jaguar, U.S.A. 2007. Jaguar XJ IntroductionAluminum Construction;

http://www.jaguarusa.com/; 13.01.2015.

5. Demeng, Z.H.Q. 2005. Research on Lightweight Design of Automobile Structure Based on ANSYS; Transactions of the Chinese Society of Agricultural Machinery, 2005-06, p: 12-15;

6. Bircan, D.A., Yaşar, A., Koca, E., 2014. Design and Analysis of Chassis using Finite Element Analysis, AVTECH'14: II. International Automotive \& Vehicle Technologies Conference; İstanbul, Türkiye.

7. Agrawal M.S., Razik M.D., 2013. Finite Element Analysis of Truck Chassis, International Journal of Engineering Sciences \& Research Technology, Vol. 2(12), p: 7685.

8. Sitaramanjaneyulu, K., Raju, V.K., 2014. Modeling and Analysis of Heavy Truck at Variable Loads; International Journal of Technology and Engineering Science, Volume 2(1), p: 1417-1424.

9. Hirsch, J., 2011. Aluminum in Innovative Light-Weight Car Design, Materials Transactions, Vol. 52(5), p: 818-824.

10.Teh, R.Y., Tong D.K.T. 2013. A Structural Investigation of an Electric Car Chassis, EURECA 2013 Conference; Taylor's University, Malaysia.

11. Riley W.B., George A.R., 2002. Design, Analysis and Testing of a Formula SAE Car Chassis; SAE Motorsports Engineering Conference and Exhibition; Indianapolis, Indiana. 